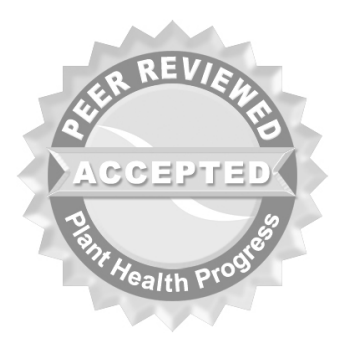

(c) 2005 Plant Management Network.

Accepted for publication 27 April 2005. Published 6 J une 2005.

\title{
Incidence of Meloidogyne incognita and Development of Resistant Soybean Germplasm in Illinois
}

J. B. Allen, Graduate Student, J. P. Bond, Assistant Professor, and M. E. Schmidt, Associate Professor, Department of Plant, Soil, and Agricultural Systems, Center of Excellence for Soybean Research, Teaching and Outreach, College of Agricultural Sciences, Southern Illinois University, Carbondale 62901

Corresponding author: Jason P. Bond. jbond@siu.edu

Allen, J. B., Bond, J. P., and Schmidt, M. E. 2005. Incidence of Meloidogyne incognita and development of resistant soybean germplasm in Illinois. Online. Plant Health Progress doi: 10.1094/PHP-2005-0606-01-RS.

\section{Abstract}

In 2002-2003, a nematode survey was conducted in the southernmost counties of Illinois. Species in eight nematode genera were detected in the survey with four genera having species considered to be important soybean pathogens. Populations of Meloidogyne incognita were detected in $6 \%$ of all fields surveyed in southern Illinois. Elite breeding lines and cultivars were evaluated for resistance to gall formation and reproduction by the nematode. Resistance was identified in several soybean genotypes.

\section{I ntroduction}

The southern root-knot nematode (Meloidogyne incognita) is a damaging pathogen of soybean (Glycine max) and other crops throughout the southern United States (13). In the 1970s, soybean yield reductions reached as high as $90 \%$ for susceptible soybean cultivars in the presence of $\mathrm{M}$. incognita in some areas (10). The impact of M. incognita on soybean production has been reduced with the availability of resistant cultivars; however, most of these cultivars were developed for the southern United States. Annual soybean yield losses to this nematode still exceed 99.6 thousand metric tons (23).

Meloidogyne incognita is predominantly found in warmer climates, at latitudes between $35^{\circ} \mathrm{S}$ and $35^{\circ} \mathrm{N}$ (21). In the Midwest, M. incognita is found in the southeastern portion of Missouri (24), southern Illinois (2), central Illinois (T. L. Niblack, personal communication), southern Indiana, and Kansas (22). All of the infested fields in Illinois were located longitudinally at the uppermost margin where the nematode was believed to survive winter temperatures (21). In 2000, two fields in White County, IL were observed exhibiting chlorotic and necrotic stunted plants and root symptoms of M. incognita (Figs. 1 and 2). Yield losses in these fields exceeded 50\% in the affected areas (1).

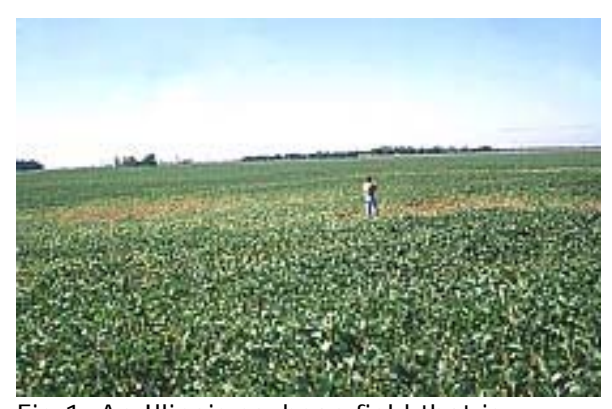

Fig 1. An Illinois soybean field that is expressing foliar symptoms resulting from Meloidogyne incognita.

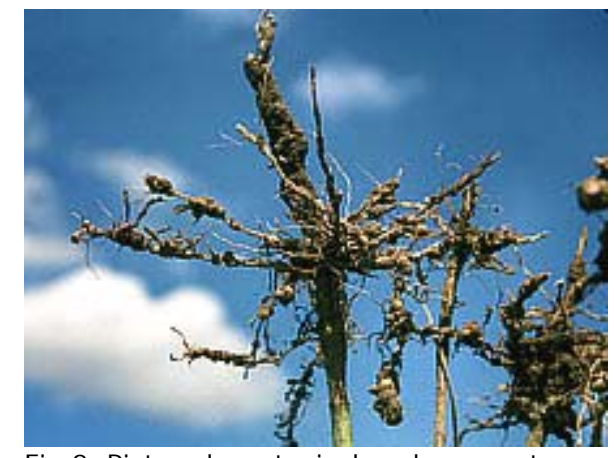

Fig 2. Pictured are typical soybean root symptoms caused by Meloidogyne incognita. 
Management options for $\mathrm{M}$. incognita in soybean are limited. Nematicides are not economical because of the relatively low value/ hectare of the crop. Crop rotation can reduce population densities; however, in the Midwest, producers often rotate soybean and corn, both of which are hosts for this pathogen $(16,20)$. Therefore, utilizing host resistance is the preferred management strategy for $\mathrm{M}$. incognita in soybean (10). Currently, the majority of soybean cultivars with resistance to M. incognita are in maturity groups V to VIII (12,17). In several southern states, early soybean production systems have been adopted resulting in the use of cultivars in maturity groups III to V. Since M. incognita is relatively new to the north central region, few adapted cultivars in maturity groups III to IV have been identified with resistance (13). The objectives of this study were to: (i) determine the incidence and distribution of plant-parasitic nematode genera in southern Illinois with a particular focus on M. incognita, and (ii) identify resistant parental germplasm, elite lines, and cultivars adapted for the lower Midwest.

\section{Nematode Survey}

Soybean fields in 17 counties of the southernmost portion of Illinois were surveyed for plant- parasitic nematodes in J uly and August 2002 and 2003. A total of 294 fields were selected and represented over 379,100 harvested hectares. Fields were identified by arbitrarily selecting global positioning system (GPS) coordinates that dissected each county in an east-west and north-south cross section. At each location, the sample consisted of a composite of 40 soil cores ( $2.5 \mathrm{~cm}$ diameter $\times 20 \mathrm{~cm}$ deep) collected in a zigzag pattern across a 20 ha area.

Nematodes were extracted from $100 \mathrm{~cm}^{3}$ of soil by wet-sieving through nested 710- $\mu \mathrm{m}$-pore, 180 - $\mu \mathrm{m}$-pore, and 25 - $\mu \mathrm{m}$-pore sieves followed by centrifugal flotation (9). J uveniles of Meloidogyne and Heterodera were identified to genus based on the morphology of the juveniles. All other nematodes were identified to genus and in some cases to species based on the morphology of adult females. In samples where Meloidogyne spp. were identified, the population was increased in the greenhouse by placing a subsample of soil into 10 -cm-diameter clay pots with 30-day-old Rutgers tomato seedlings (Lycopersicon esculentum). After 90 days, the species of Meloidogyne were determined by examination of the perineal patterns (4) and by using the North Carolina Host Differential assay.

\section{I ncidence and Distribution of Plant-Parasitic Nematodes}

The total area surveyed represents $1.4 \%$ of the soybean hectarage in the southernmost cropping districts in Illinois. Eight genera of plant-parasitic nematodes were found with varying frequencies in the 17 counties included in the survey (Table 1). Cysts of $\mathrm{H}$. glycines were found in $74 \%$ of fields, with an average of 32 cysts and a maximum of 615 cysts per $100 \mathrm{~cm}^{3}$ of soil. Meloidogyne incognita averaged 10 juveniles per $100 \mathrm{~cm}^{3}$ of soil with a maximum of 1,356 per $100 \mathrm{~cm}^{3}$ of soil. At one location, juveniles of Meloidogyne spp. were identified; however, attempts to culture this population for identification were not successful. Two other important genera in soybean and rotational crops, Hoplolaimus and Pratylenchus, were detected in 25\% and 39\% of the fields, respectively. Paratylenchus spp., Tylenchorhynchus spp., and Xiphinema spp. were found at low frequencies and densities in the survey. All of the genera detected in this survey contain species that are parasites of soybean; however, only species in Pratylenchus, Hoplolaimus, Meloidogyne, and Heterodera are considered to be damaging pathogens of soybean $(11,15)$. 
Table 1. The incidence of plant-parasitic nematodes in soybean fields in southern Illinois.

\begin{tabular}{|l|c|c|c|}
\hline \multirow{2}{*}{ Taxon } & \multirow{2}{*}{$\begin{array}{c}\text { Frequency } \\
(\%)\end{array}$} & Mean & Maximum \\
\cline { 3 - 4 } & 89 & 177 & 984 \\
\hline Helicotylenchus spp. & & & \\
\hline Heterodera glycines & 74 & 32 & 615 \\
\hline Cysts & 30 & 94 & 3,252 \\
\hline Juveniles & 25 & 6 & 213 \\
\hline Hoplolaimus galeatus & 6 & 10 & 1,356 \\
\hline Meloidogyne incognita & 39 & 14 & 369 \\
\hline Pratylenchus spp. & 3 & 1 & 164 \\
\hline Paratylenchus spp. & 20 & 10 & 303 \\
\hline Tylenchorhynchus spp. & 5 & 1 & 74 \\
\hline Xiphinema spp. & & & of soil \\
\hline
\end{tabular}

Samples collected in July and August, 2002 and 2003.

Meloidogyne incognita was detected in 9 of the 17 counties surveyed (Fig. 3, Table 2). Infested fields were identified primarily in the eastern and westernmost counties of southern Illinois. In counties where the nematode was identified, the percentage of the fields infested ranged from a low of $4 \%$ in Perry County to a high of $20 \%$ in Edwards County. The percentage of infested fields in Alexander and White counties were $14 \%$ and $19 \%$, respectively. Fields exhibiting foliar symptoms were observed in these two counties. Across the 17 counties, an average of $6 \%$ of the fields surveyed was infested with $M$. incognita. Counties included in this survey are relatively close to production fields in Indiana, Kentucky, and Missouri that have been reported to be infested with M. incognita.

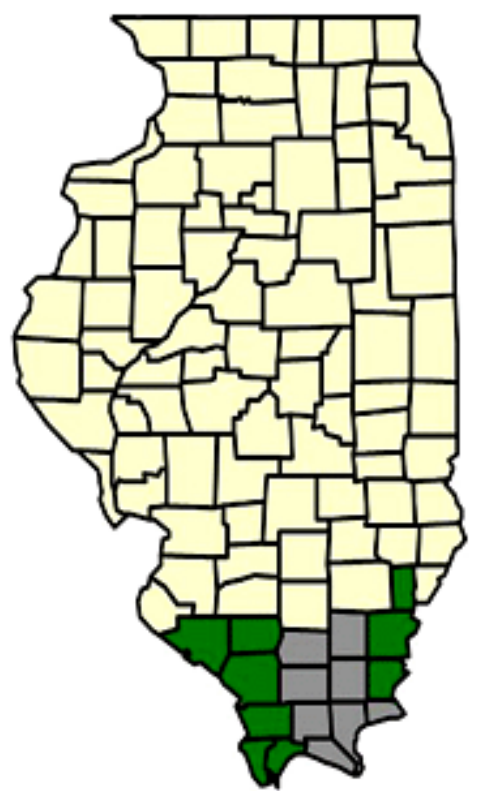

Fig 3. Highlighted are the 17 counties included in this survey. Counties with dark green shading were infested with

Meloidogyne incognita. The nematode was not detected in the counties that are shaded in light gray. 
Table 2. Illinois counties sampled for nematodes, year sampled, soybean hectares harvested in year sampled, and detection of Meloidogyne incognita.

\begin{tabular}{|c|c|c|c|c|}
\hline County & Year & $\begin{array}{l}\text { Samples } \\
\text { collected }\end{array}$ & $\begin{array}{c}\text { Hectares } \\
\text { harvested } \\
\text { (thousands) }\end{array}$ & $\begin{array}{l}\text { I nfested fields } \\
\text { ( no. of fields / } \\
\text { percentage) }\end{array}$ \\
\hline Alexander & 2002 & 14 & 16.1 & $2 / 14$ \\
\hline Edwards & 2003 & 5 & 17.2 & $1 / 20$ \\
\hline Franklin & 2003 & 23 & 29.8 & $0 / 0$ \\
\hline Gallatin & 2002 & 20 & 27.3 & $3 / 15$ \\
\hline Hamilton & 2002 & 20 & 35.7 & $0 / 0$ \\
\hline Hardin & 2003 & 10 & 2.8 & $0 / 0$ \\
\hline Jackson & 2002 & 20 & 34.6 & $2 / 10$ \\
\hline Johnson & 2002 & 10 & 7.2 & $0 / 0$ \\
\hline Massac & 2002 & 14 & 16.9 & $0 / 0$ \\
\hline Perry & 2003 & 23 & 36.7 & $1 / 4$ \\
\hline Pope & 2003 & 14 & 4.1 & $0 / 0$ \\
\hline Pulaski & 2002 & 21 & 14.8 & $2 / 9.5$ \\
\hline Randolph & 2002 & 20 & 41.8 & $2 / 5$ \\
\hline Saline & 2002 & 20 & 22.5 & $0 / 0$ \\
\hline Union & 2002 & 21 & 12.9 & $2 / 9.5$ \\
\hline White & 2002 & 21 & 49.8 & $4 / 19$ \\
\hline Williamson & 2003 & 18 & 8.9 & $0 / 0$ \\
\hline Total & $2002-2003$ & 294 & 379.1 & $18 / 6$ \\
\hline
\end{tabular}

\section{Germplasm Evaluation}

Soybean germplasm lines were selected for evaluation based on agronomic performance and their potential for release as germplasm or cultivars (Table 3). These consisted of elite breeding lines, public and private cultivars, and the susceptible control (Pickett) and the resistant control (Forrest). Seed of these genotypes were obtained from the soybean breeding program at Southern Illinois University Carbondale (SIUC). The majority of the SIUC germplasm was selected based on resistance to Heterodera glycines, soybean sudden death syndrome, or a combination of the two. 
Table 3. Relative maturity, parentage, resistance level, and source of resistance to Heterodera glycines, Race 3 (Type 0), for selected genotypes.

\begin{tabular}{|c|c|c|c|c|}
\hline Genotypes & $\begin{array}{l}\text { Relative } \\
\text { maturity }\end{array}$ & Parents & $\begin{array}{c}\text { H.g. } \\
\text { resistance } \\
\text { level }^{a}\end{array}$ & $\begin{array}{c}\text { Source } \\
\text { of H.g. } \\
\text { resistance }\end{array}$ \\
\hline LS90-1920 & 4.9 & Essex $\times$ Fayette & $\mathrm{HR}$ & PI88788 \\
\hline LS93-0375 & 4.3 & A3935 × P9402 & $\mathrm{HR}$ & PI88788 \\
\hline LS94-3207 & 4.7 & Pharaoh $\times$ Hartwig & $\mathrm{HR}$ & $\mathrm{PI} 437654$ \\
\hline LS96-1631 & 5.2 & LS79-238 $\times$ Hutcheson & MR & Peking \\
\hline LS97-1610 & 5.0 & S90-1435 × Manokin & $\mathrm{R}$ & $\begin{array}{l}\text { PI89772, } \\
\text { Peking }\end{array}$ \\
\hline LS97-3004 & 4.2 & Pharaoh $\times$ K1191 & $\mathrm{HR}$ & Peking \\
\hline LS97-3221 & 4.1 & Pioneer $9521 \times$ LS92-1800 & $\mathrm{HR}$ & PI88788 \\
\hline LS98-1771 & 4.7 & LS79-238 x LS92-1800 & $\mathrm{HR}$ & Peking \\
\hline LS98-3966 & 5.0 & LS90-1920 $\times$ Hutcheson & $\mathrm{HR}$ & PI88788 \\
\hline LS98-1782 & 4.7 & LS79-238 x LS92-1800 & $\mathrm{HR}$ & na \\
\hline LS99-1308 & 4.9 & LS90-1920 × KY88-4080 & $\mathrm{HR}$ & PI88788 \\
\hline LS99-1615 & 5.0 & LS79-238 x KY88-4080 & $\mathrm{HR}$ & Peking \\
\hline LS99-1802 & 5.1 & LS90-1920 × NK52-25 & $\mathrm{HR}$ & na \\
\hline LS99-3319 & 4.9 & LS90-1920 × KY88-4080 & $\mathrm{HR}$ & PI88788 \\
\hline LS99-3630 & 4.9 & LS79-238 × KY88-4080 & HR & Peking \\
\hline LS99-3619 & 4.9 & LS79-238 × KY88-4080 & $\mathrm{HR}$ & Peking \\
\hline LS99-3639 & 4.9 & LS90-1920 × NK52-25 & $\mathrm{HR}$ & PI88788 \\
\hline LS99-3730 & 5.0 & Asgrow5560 × KY88-4080 & $\mathrm{R}$ & na \\
\hline ExF11-32 & 5.3 & Essex $\times$ Forrest & $\mathrm{HR}$ & Peking \\
\hline ExF59 & 5.2 & Essex $\times$ Forrest & $\mathrm{HR}$ & Peking \\
\hline ExF20-16 & 5.3 & Essex $\times$ Forrest & $\mathrm{R}$ & Peking \\
\hline ExF20-32 & 5.3 & Essex $\times$ Forrest & $\mathrm{N}$ & Peking \\
\hline ExF11-1 & 5.3 & Essex $\times$ Forrest & $\mathrm{HR}$ & Peking \\
\hline K1423 & 4.9 & Manokin $\times$ LS86- 1922 & $\mathrm{HR}$ & na \\
\hline K1425 & 4.9 & Hartwig $\times$ KS4895 & $\mathrm{HR}$ & $\mathrm{PI} 437654$ \\
\hline Manokin & 4.9 & L70-L3048 × D74-7824 & $\mathrm{HR}$ & Peking \\
\hline MD93-5634 & 5.0 & K1173 $\times$ Corsica & $\mathrm{L}$ & na \\
\hline N96-180 & 5.6 & N87-298 $\times$ Cook & $\mathrm{L}$ & na \\
\hline TN96-68 & 5.1 & N85-578 $\times$ Manokin & $\mathrm{N}$ & na \\
\hline TN96-58 & 5.3 & Hutcheson $\times$ TN89-39 & $\mathrm{N}$ & na \\
\hline $\begin{array}{l}\text { Pioneer } \\
\text { 9492RR }\end{array}$ & 4.9 & NA & $\mathrm{HR}$ & $\begin{array}{l}\text { PI88788, } \\
\text { Peking }\end{array}$ \\
\hline $\begin{array}{l}\text { Pioneer } \\
\text { 94B81RR }\end{array}$ & 4.8 & NA & $\mathrm{L}$ & PI88788 \\
\hline Pickett & 6.2 & $\begin{array}{l}\text { NC55- } 1 \times[\text { D49-2491 (6) } \\
\times \text { Dorman] }\end{array}$ & HR & Peking \\
\hline Forrest & 5.5 & Dyer $\times$ Bragg & $\mathrm{HR}$ & Peking \\
\hline
\end{tabular}

${ }^{a}$ Resistance scale based on Heterodera glycines female index (\# females on genotype / \# females on Lee 74$) \times 100$. Female index range for highly resistant $(H R)$, resistant $(R)$, moderately resistant (MR), low resistance (L), and no effective resistance $(\mathrm{N})$ are $0-9,10$ $24,25-39,40-59$, and $>60$, respectively. na $=$ Not available. 
Soybean genotypes were separated into two experiments, both of which were conducted twice. The first experiment evaluated genotypes that served as parents in the SIUC breeding program, and the second experiment included elite breeding lines and cultivars.

The population of $\mathrm{M}$. incognita used in this research was obtained from a producer's field in White County, IL. This field has a history of corn and soybean rotation that occasionally included winter wheat or spring green bean with soybean as a double crop. Meloidogyne incognita was maintained for 120 days in 10-cm-diameter clay pots containing $5.5 \mathrm{~kg}$ of a steam-pasteurized soil (ca. $75 \%$ sand, $16 \%$ silt, 9\% loam, < 1\% O.M.) on Rutgers tomato, L. esculentum. For inoculum preparation, eggs were collected from infected root systems using the method of Hussey and Barker (5).

For each trial, genotypes were arranged in a randomized complete block design, and replicated five times. Two soybean seeds of each genotype were planted in $150-\mathrm{cm}^{3}$ Cone-tainers (Stuewe and Sons, Corvallis, OR) containing soil as described above. Five to seven days following emergence, plants were thinned to one plant per Cone-tainer, and the soil was infested with 5,000 eggs at a depth of $6.3 \mathrm{~mm}$ (Fig. 4) (8). Greenhouse temperatures were maintained within 28 to $32^{\circ} \mathrm{C}$ and plants were watered twice daily as needed.

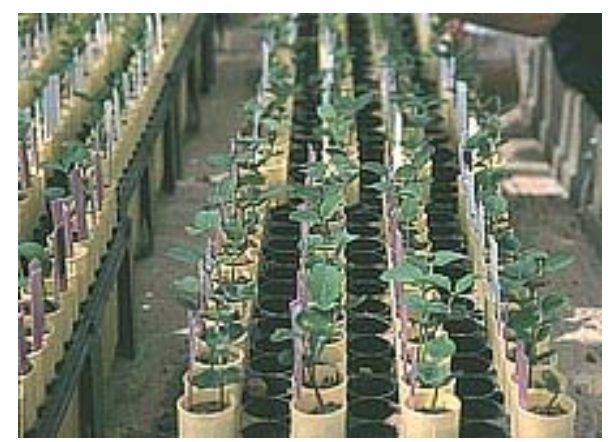

Fig 4. Pictured is the Cone-tainer system that was used in the greenhouse resistance evaluation and the size of seedlings at infestation with Meloidogyne incognita.

Forty-five days after infestation, plants were removed from the Cone-tainers, the root systems weighed, and the severity of root galling determined (Fig. 5). Roots were rated on a 0 to 5 scale based on the number of galls per root system: $0=0,1=1$ to $2,2=3$ to $10,3=11$ to $30,4=31$ to $100,5=>100$ galls per root system (6). Nematode eggs were extracted from roots (5), counted using a stereomicroscope ( $30 \times$ magnification), and converted to eggs per $g$ of root. Resistance was based on reduced galling and egg production relative to the susceptible control.

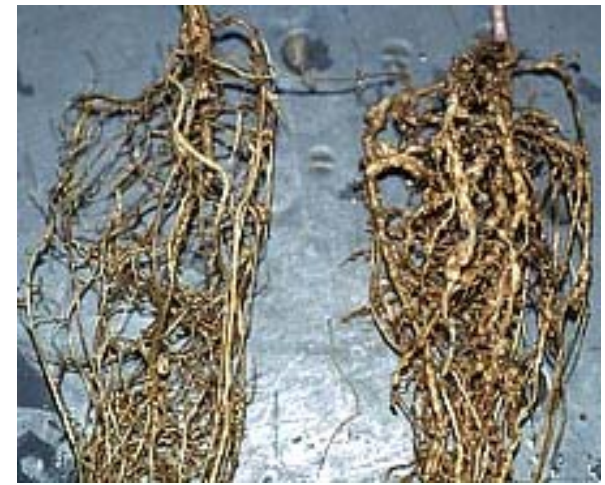

Fig 5. Root galls and swelling on a susceptible cultivar (right) as compared to the resistant cultivar, Forrest (left). 
Data were tested for normality and transformed $(\log (x+1))$ where appropriate. All data were subjected to analysis of variance (ANOVA) with SAS version 6.1(SAS Institute, Cary, NC) General Linear Model. Means were separated using Fisher's LSD test and differences noted at $(\mathrm{P} \leq 0.05)$.

\section{Resistance I dentified in Adapted Germplasm}

The genotypes tested, relative maturity, parentage, resistance level to $\mathrm{H}$. glycines, and the source of resistance are presented (Table 3). For each experiment, there was no genotype by trial interaction; therefore data for trials were combined within each experiment. Differences $(P \leq 0.05)$ were observed among the genotypes for gall index and reproduction by $\mathrm{M}$. incognita (Tables 4 and 5).

Table 4. Gall index and reproduction by Meloidogyne incognita on selected cultivars and parental soybean lines.

\begin{tabular}{|c|c|c|c|c|}
\hline \multirow{2}{*}{$\frac{\text { Genotypes }^{a}}{\text { LS97-3221 }}$} & \multicolumn{2}{|c|}{ Gall index $b$} & \multicolumn{2}{|c|}{ Eggs per $g$ of root $\times 10^{3 \mathrm{C}}$} \\
\hline & 5.0 & a & 126.3 & a \\
\hline Pickett & 5.0 & a & 58.7 & $\mathrm{~b}$ \\
\hline P 9492 RR & 5.0 & a & 47.0 & bc \\
\hline P 94B81 RR & 5.0 & a & 45.4 & bc \\
\hline TN96-68 & 4.8 & a & 33.6 & $\mathrm{~cd}$ \\
\hline ExF11-32 & 4.8 & a & 25.2 & cdef \\
\hline MD93-5634 & 4.0 & $a b$ & 27.6 & cde \\
\hline LS98-1771 & 3.5 & $a b$ & 13.3 & defgh \\
\hline Manokin & 2.5 & abcd & 3.3 & fgh \\
\hline LS97-3004 & 2.5 & abcd & 1.8 & gh \\
\hline K1423 & 2.0 & bcde & 27.8 & cde \\
\hline K1425 & 2.0 & bcde & 22.5 & defg \\
\hline ExF59 & 1.8 & cde & 2.1 & gh \\
\hline ExF20-16 & 1.7 & def & 5.9 & efgh \\
\hline N96-180 & 1.3 & def & 0.7 & gh \\
\hline LS98-1782 & 1.0 & ef & 3.4 & fgh \\
\hline ExF11-1 & 1.0 & ef & 0.6 & gh \\
\hline Forrest & 0.5 & ef & 2.1 & gh \\
\hline TN96-58 & 0.3 & $f$ & 0.7 & gh \\
\hline ExF20-32 & 0.3 & $f$ & 0.4 & $\mathrm{~h}$ \\
\hline
\end{tabular}

${ }^{a}$ Forrest and Pickett were the resistant and susceptible controls, respectively.

${ }^{b}$ Gall index: $0,1,2,3,4,5=0,1-2,3-10,11-30,31-100,>100$ galls per root system, respectively.

${ }^{\mathrm{C}}$ Data are the means of two trials and five replicates per trial $(\mathrm{N}=10)$. Means were transformed for normality prior to conducting mean separations; however, means presented are not transformed.

Within columns, means followed by the same letter are not significantly different $(P \leq 0.05)$ according to Fisher's Protected LSD test. 
Table 5. Gall index and reproduction by Meloidogyne incognita on soybean cultivars and elite lines.

\begin{tabular}{|l|c|c|c|c|}
\hline Genotype & \multicolumn{2}{|c|}{ Gall index } & \multicolumn{2}{c|}{ Eggs per g of root $\times \mathbf{1 0}^{\mathbf{3}}$} \\
\hline LS96-1631 & 5.0 & $\mathrm{a}$ & 46.5 & $\mathrm{a}$ \\
\hline LS99-1802 & 5.0 & $\mathrm{a}$ & 28.9 & $\mathrm{ab}$ \\
\hline LS99-3319 & 5.0 & $\mathrm{a}$ & 12.7 & $\mathrm{abc}$ \\
\hline LS99-3730 & 5.0 & $\mathrm{a}$ & 8.3 & $\mathrm{bcd}$ \\
\hline Pickett & 5.0 & $\mathrm{a}$ & 5.0 & $\mathrm{bcde}$ \\
\hline LS99-1615 & 5.0 & $\mathrm{a}$ & 5.1 & $\mathrm{bcde}$ \\
\hline LS99-3630 & 5.0 & $\mathrm{a}$ & 3.7 & $\mathrm{cdef}$ \\
\hline LS93-0375 & 4.8 & $\mathrm{a}$ & 5.2 & $\mathrm{bcde}$ \\
\hline LS99-3619 & 3.8 & $\mathrm{ab}$ & 5.8 & bcde \\
\hline LS99-3639 & 3.0 & $\mathrm{bc}$ & 3.6 & cdef \\
\hline LS94-3207 & 1.8 & $\mathrm{~cd}$ & 1.0 & def \\
\hline LS97-1610 & 1.8 & $\mathrm{~cd}$ & 0.9 & ef \\
\hline LS99-1308 & 1.8 & $\mathrm{~cd}$ & 0.7 & ef \\
\hline LS98-3966 & 1.5 & $\mathrm{de}$ & 0.6 & ef \\
\hline LS90-1920 & 1.3 & $\mathrm{de}$ & 1.0 & def \\
\hline Forrest & 0.3 & $\mathrm{e}$ & 0.4 & e \\
\hline
\end{tabular}

${ }^{a}$ Forrest and Pickett were the resistant and susceptible controls, respectively.

b Gall index: $0,1,2,3,4,5=0,1-2,3-10,11-30,31-100,>100$ galls per root system respectively.

${ }^{\mathrm{C}}$ Data are the means of two trials and five replicates per trial $(\mathrm{N}=10)$. Means were transformed for normality prior to conducting mean separations; however, means presented are not transformed.

Within columns, means followed by the same letter are not significantly different $(P \leq 0.05)$ according to Fisher's Protected LSD test.

In the first experiment, six of the 18 genotypes had less galling and nematode reproduction than Pickett (Table 4). Of these nine genotypes, five can be classified as resistant and four as moderately resistance based on gall index. Typically, soybean genotypes with gall indices ( 0 to 5 scale) of $\leq 1.5$ are considered resistant, indices of 1.6 - 2.5 moderately resistant, and indices $\geq 2.6$ are considered susceptible (7). In addition, eight of the nine genotypes did not differ from Forrest with regards to gall index and nematode reproduction (Table 4).

In the second experiment, nine of the 14 genotypes tested were different from Pickett based on gall index (Table 5). However, neither Forrest nor the 14 genotypes were different from Pickett based on egg production. The inability to separate Pickett from the other genotypes was probably due to the low egg production on Pickett in the second experiment. The genotypes LS99-3639, LS94-3207, LS97-1610, and LS99-1308 had a reduced gall index relative to Pickett. The genotypes LS98-3966 and LS90-1920 could be classified as resistant based on a low gall index (<1.5). Both genotypes exhibited a lower gall index than Pickett and were similar to Forrest.

A significant linear relationship existed between gall index and reproduction for Experiment $1\left(\mathrm{R}^{2}=0.77, \mathrm{P}<0.001\right)$ and Experiment $2\left(\mathrm{R}^{3}=0.79, \mathrm{P}<\right.$ 0.001). Determination of gall index is not as laborious as determination of reproduction. Thus, breeding programs would be best served to select resistant genotypes based on gall index in preliminary evaluations, followed by selection based on nematode reproduction in advanced evaluations (8).

Resistance to M. incognita in Forrest is conditioned by a single additive gene $\mathrm{Rmi}_{1}$ (14). Several genotypes identified as resistant in this study have Forrest in their pedigree and may possess this gene. However, LS90-1920, LS98-3966, and 
N96-180 do not have Forrest in their pedigree and may possess unique genes for resistance. Resistance in N96-180 may have come from the cultivar Cook, which is moderately resistant to M. incognita (3); however, the resistance status of the other parent, N87-298, is unknown (J. W. Burton, personal communication). Both parents of LS90-1920, Essex and Fayette, are susceptible; therefore, it is difficult to determine the source of the resistance in this cultivar. LS98-3966 was derived from the cross LS90-1920 $\times$ Hutcheson, indicating that resistance from LS90-1920 was heritable. However, inheritance studies have not been conducted.

\section{Conclusions}

Species in eight nematode genera were detected in the survey with four of these having species considered to be important soybean pathogens. Meloidogyne incognita was found in $6 \%$ of all fields surveyed in southern Illinois. Many fields in the southeastern and southwestern regions of Illinois contain lighter texture soils and are more conducive for establishment and the subsequent detection of $\mathrm{M}$. incognita. The nematode was found to a lesser extent in the heavier clay soils that are more typical of south-central Illinois. At this time, it is not possible to determine the potential threat of the nematode in areas with a greater percentage of heavier clay soils. While this nematode is a threat to soybean producers in the lighter texture soils of the state, it poses even a greater threat to vegetable and orchard crops that are prevalent in southern Illinois.

Many of the genotypes under evaluation herein were selected based upon their having potential for release as germplasm or cultivars. Several of these were identified as resistant to $\mathrm{M}$. incognita. Though many of these soybean lines likely possess qualitative resistance tracing back to Forrest, a few may possess as yet unidentified genes for resistance.

Several M. incognita-resistant genotypes identified in this study are cultivars and have been recommended to producers for fields infested with M. incognita. The cultivars LS90-1920 and LS94-3207 are high yielding and also possess resistance to $\mathrm{H}$. glycines and to sudden death syndrome $(18,19)$. LS97-1610 has been released as germplasm because this genotype also possesses resistance to H. glycines and to sudden death syndrome.

\section{Acknowledgments}

This project was funded by the Illinois Soybean Program Operating Board and the Illinois Council on Food and Agricultural Research. The authors would like to thank A. K. Gregor, W. P. Bond, and two anonymous reviewers for critically reviewing this manuscript.

\section{Literature Cited}

1. Allen, J. B., Bond, J. P., Schmidt, M. E., Walters, S. A. and Russin, J . S. 2002. Impact of Meloidogyne incognita on soybean varieties in Illinois. (Abstr.) Phytopathology 92:S3.

2. Bond, J. P., Schmidt, M. E., Walters, S. A. and Russin, J. S. 2002. Meloidogyne incognita, a new threat to soybean production in Illinois. (Abstr.) Nematology $4: 209$.

3. Boerma, H. R., Hussey, R. S., Phillips, D. V., Wood, E. D., and Finnerty, S. L. 1992. Registration of Cook soybean. Crop Sci. 32:497.

4. Eisenback, J. D. 1985. Diagnostic characters useful in the identification of the four most common species of root-knot nematodes (Meloidogyne spp.) Pages 95-112 in: An Advanced Treatise on Meloidogyne, Vol. 1. Biology and Control. J . N. Sasser and C. C. Carter, eds. North Carolina State University Graphics, Raleigh, North Carolina.

5. Hussey, R. S., and Barker, K. R. 1973. A comparison of methods of collecting inocula of Meloidogyne spp., including a new technique. Plant Dis. Rep. 57:1025-1028.

6. Hussey, R. S., and Boerma, H. R. 1981. A greenhouse screening procedure for rootknot nematode resistance in soybeans. Crop Sci. 21:794-796.

7. Hussey, R. S., Boerma, H. R., Raymer, P. L., and Luzzi, B. M. 1991. Resistance in soybean cultivars from maturity groups V-VIII to soybean cyst and root-knot nematodes. J. Nematol. 23:576-583. 
8. Hussey, R. S., and J anssen, G. J . W. 2004. Root-knot nematode: Meloidogyne species. Pages 43-70 in: Plant Resistance to Parasitic Nematodes. J . L. Starr, R. Cook, and J. Bridge, eds. CABI Publishing, New York.

9. J enkins, W. R. 1964. A rapid centrifugal flotation technique for separating nematodes from soil. Plant Dis. Rep. 48:692.

10. Kinloch, R. A. 1974. Response of soybean cultivars to nematicidal treatments of soil infested with Meloidogyne incognita. J . Nematol. 6:7-11.

11. Kinloch, R. A. 1998. Soybean. Pages 317-333 in: Plant Nematode Interactions. K. R. Barker, G. A. Pederson, and G. L. Windham, eds. ASA, CSSA, SSSA, Madison, WI.

12. Kinloch, R. A., and Kabana, R. R. 1999. Root-knot nematodes. Pages 55-57 in: Compendium of Soybean Diseases, 4th ed. G. L. Hartman, J . B. Sinclair, and J . C. Rupe, eds. American Phytopathological Society Press, St. Paul, MN.

13. Kirkpatrick, T. L., and May, M. L. 1989. Host suitability of soybean cultivars for Meloidogyne incognita and M. arenaria. J . Nematol. 21:666-670.

14. Luzzi, B. M., Boerma, H. R., and Hussey, R. S. 1994. A gene for resistance to the southern root-knot nematode in soybean. J . Hered. 85:484-486.

15. Niblack, T. L., Tylka, G. L., and Riggs, R. D. 2004. Nematode pathogens of soybean. Pages 821-851 in: Soybeans: Improvement, Production and Uses, 3rd ed. H. R. Boerma and J . E. Specht, eds. ASA, CSSA, SSSA, Madison, WI.

16. Norton, D. C. 1984. Nematode parasites of corn. Pages 63-75 in: Plant and Insect Nematodes. W. R. Nickle, ed. Marcel Dekker Inc, New York.

17. Riggs, R. D., Hamblen, M. L., and Rakes, L. 1988. Resistance in commercial soybean cultivars to six races of Heterodera glycines and to Meloidogyne incognita. Ann. of Appl. Nematol. 2:70-76.

18. Schmidt, M. E., Klein, J ., Suttner, R. J ., and Myers, O., J r. 1999. Registration of 'LS90-1920' soybean. Crop Sci. 39;295.

19. Schmidt, M. E., and Klein, J . H. 2004. Registration of 'LS94-3207' soybean. Crop Sci. 44:1482-1483.

20. Schmitt, D. P., and Noel, G. R. 1984. Nematode parasites of soybean. Pages 14-43 in: Plant and Insect Nematodes. W. R. Nickle, ed. Marcel Dekker Inc. New York.

21. Taylor, A. L., and Sasser, J. N. 1978. Biology, identification and control of root-knot nematodes (Meloidogyne species). North Carolina State University, Raleigh, NC.

22. Walters, S. A., and Barker, K. R. 1994. Current distribution of five major Meloidogyne species in the United States. Plant Dis. 78:772-774.

23. Wrather, J. A., Koenning, S. R., and Anderson, T. R. 2003. Effects of diseases on soybean yield in the United States and Ontario (1999 to 2002). Online. Plant Health Progress doi:10.1094/ PHP-2003-0325-01-RV.

24. Wrather, J . A., Niblack, T. L., and Milam, M. R. 1992. Survey of plant-parasitic nematodes in Missouri cotton fields. J . Nematol. (suppl.) 24:779-782. 